\title{
Management of Sustainable Innovation in an Internationalized Company
}

\author{
Uiara De Menezes',Valéria Dias², Clandia Gomes ${ }^{3}$, Flávia Scherer ${ }^{4}$, Isak Kruglianskas ${ }^{5}$
}

\begin{abstract}
The main objective of this study was to identify the main forms of management of sustainable technological innovation and examine the relation of these practices with the increased competitiveness of the Brazilian chemical industry in the international market. To conduct this research, we examined the management practices of a chemical industry located in southern Brazil through the descriptive and qualitative case study, using semi-structured interviews with those responsible for the company's innovation management and analyzing secondary data. The analyses of the survey results with respect to the relation between the sustainable technological innovation management and the increased international competitiveness of the chemical industry were not conclusive. The data only show that the management practices of sustainable innovation may represent motivations for seeking international partnerships and innovations that can be converted into business opportunities in the domestic and international market
\end{abstract}

Keywords: innovation management; sustainability; internationalization; chemical industry.

\footnotetext{
'Escola de Administração. Universidade Federal do Rio Grande do Sul. Andrade Neves Street, 875, 03, Caxias do Sul, Brazil. Zip Code 95080-240. Phone +55 54 9162-8978. E-mail: uiara.menezes@gmail.com

${ }^{2}$ Centro de Estudos e Pesquisas em Agronegócios. Universidade Federal do Rio Grande do Sul/ Faculdade Palotina. Bento Gonçalves Avenue, 77 I 2, Porto Alegre, Brazil. Zip Code 91540-000. Phone +55 55 3220-4575. E-mail: valeria-adm@hotmail.com

${ }^{3,4}$ Centro de Ciências Sociais e Humanas. Universidade Federal de Santa Maria. Roraima Avenue, 1000, Prédio 74 C, sala 4303, Cidade Universitária, Santa Maria, Brazil. Zip Code 97105-900. Phone +55 55 3220-9258. E-mail: 'clandiamg@gmail.com, ²flaviascherer@globo.com

${ }^{5}$ Faculdade de Economia, Administração e Contabilidade. Universidade de São Paulo. Av. Prof. Luciano Gualberto, 908, Butantã, São Paulo, Brazil. Zip Code 05508-010. Phone +55I I 309I-5960. E-mail: ikruglia@gmail.com
}

ISSN: 07I 8-2724. (http://www.jotmi.org)

Journal of Technology Management \& Innovation (c) Universidad Alberto Hurtado, Facultad de Economía y Negocios. 


\section{Introduction}

The Brazilian industry is characterized as one of the largest and most diversified industries in the developing countries, generating output, exports and jobs, which are crucial for the sustainable economic development and improved living conditions of the population. New technologies and forms of organizing production have ensured a more dynamic and competitive recognition of the country's industry in the global market, whose competitiveness is based on the differentiation of products and processes, and technological innovation is the key element. Moreover, technological innovation is one of the drivers of competition and industrial development. During the past 20 years, various technological changes, particularly those derived from the growth of the information and communication technologies, have changed the products, processes, ways of use, and people's lifestyle thoroughly (DE NEGRI et al., 2005).

Innovation, when associated with environmental concerns and intended to achieve the corporation's goals, can give rise to important innovation technologies through increased output efficiency, new business opportunities or environmentally-friendly products Characteristics such as knowledge on the market and focus on research and development (R\&D) increase the chances of an organization to deliver new solutions to increase its competitive market share and promote business opportunities (DAROIT and NASCIMENTO, 2000). A very dynamic sector is the chemical industry, which participates actively in the industrial chain in Brazil, with total imports of 26.I billion dollars, mainly from North America and the European Union, and a total of exports of 10.4 billion dollars, especially to the Mercosul and North America countries in 2009 (ABIQUIM, 20I0).

The chemical industry creates innovation opportunities and provides a wide range of benefits to society, because there has always been a strong relation between global development and chemical innovation. Moreover, this industry has made efforts on the development of activities that ensure the operations sustainability, particularly regarding social and environmental issues, the so-called chemical safety (ABIQUIM, 20I0).

The representativeness of the Brazilian chemical industry and the importance of innovation and internationalization matters in the academic and corporate context justify this study, whose main goal is to identify how sustainable technological innovation is managed and verify whether the sustainable technological innovation management is linked to the increased participation in the international market.

\section{Management of Technological Innovation and Sustainable Development}

Innovation is a process of converting opportunities into new ideas to be used in a practical way, i.e., innovate is to explore new ideas successfully (TIDD et al., 1997), or, according to Schumpeter (1984), innovate means to produce new things, or the same things in different manners, combining various strengths and materials.

Innovations can be of many types. According to the Oslo Manual (2005) innovations are divided into product, process, organization, and marketing innovations. Product innovation refers to the introduction of a new product or service or a significantly improved product or service with respect to its characteristics or usages. Process innovation is the implementation of a new, or a significantly improved method of production or distribution, consisting of significant changes in techniques, equipment and/or software. Marketing innovation suggests the implementation of a new method of commercialization with significant changes in product design or packaging, in product positioning, promotion or pricing. Finally, organizational innovation deals with the implementation of a new organizational method in the firm's business practices, in the organization of the workplace or external relations.

Damanpour (1991) highlights the difference between technological innovation and administrative innovation. Technological innovation refers to products, services and technology or processes for technological production, and is related to the basic work activities. Administrative innovation involves the organizational structure and administrative processes and is directly related to the management of work activities of an organization.

In order to deliver technological innovation and sophistication, organizations need to invest a minimum in R\&D to outstrip competitors, or at least cope with them, develop technologies to improve productivity and be able to create niche market in sectors where the domestic companies have some competitive advantage (GENTZOGLANIS, 1997).

Decision on the use of internal or external sources of innovation is part of the firm's innovation strategy (LINDER et al., 2003a). So, technology acquisition is an important decision, and the success of an innovation is associated with the development and integration of new knowledge to the innovation process (CASSIMAN and VEUGELERS, 2000).

Technological innovation sources are quite valuable to the innovation process in organizations. Knowing the kinds of sources enable the companies to understand which technological effort has to be accomplished (PORTO et al., 2003).

ISSN: 07 I8-2724. (http://www.jotmi.org) 
Authors such as Baranãno (1998) and Quadros et al. (200I) found in their studies that technological information sources are crucial for the organizational innovation. The interactions between sciences and technology and the markets are requirements considered by Vieira and Ohayon (2002) during the innovation process. Therefore, the establishment of networks with public and private research centers, firms, users and suppliers are vital for them to promote, by means of such arrangements, the development and diffusion of innovations. This is corroborated by Gomes (2007), who inferred that managing a diversity of sources and the complex relationships established between the partners in the innovation activity is key to the company's development.

Due to the various modalities of access to technology, with different information sources for innovation and the company's internal and external efforts, cooperation between the diverse stakeholders involved in the innovation process is necessary, and so collaboration between such actors are all-important, once the innovation activities involve efforts of research and development of processes and products, either performed in-house or outside, in addition to technology transfer through licensing agreements or other forms of technological exchange (FERRAZ, KUPFER and HAGUENAUER, 1995). Among such forms of mutual collaboration are those cited by Tidd et al. (1997): subcontracting or outsourcing, technology licensing, research consortium, strategic alliances, joint ventures, and innovation channels.

The association of innovation with environmental concerns may give rise to key technological innovations, which may vary from minor improvements in routine activities to major modifications of products and processes according to the organizational goals (DAROIT And Nascimento, 2000). Such interaction is corroborated by Hall and Vredenburg (2003), when they infer that to be in line with sustainable development, innovations should take into account current social and environmental needs and those of future generations.

At the same time, product and process innovations can work as catalysts to improve the companies' environmental performance by means of benefits or advantages, such as costs reduction, increased productivity, and opening of new markets, and reach a competitive position ahead of competitors. When companies comply with the requirements of environmental laws, they develop technological innovations by taking advantage of the opportunities resulting from changes of products, processes, and traditional operational methods. Such innovations result in an increased competitiveness of these companies (PORTER And Van Der Linde, 1995).

The integration of technological innovation with sustainability provides technological innovation-oriented development, or sustainable technological innovation, which is conceptualized by Hansen et al. (2009) as innovations that maintains or increase the company's overall assets (economic, environmental and social). The authors also add that from the business viewpoint, there is consensus that the challenges of sustainability provide a significant potential for innovations as well as for the development of business opportunities. The sustainability criteria must be integrated to the innovation process and guide the development and creation of innovations to ensure sustainability.

There are evidences that technological innovations have a positive impact on the companies' increased competitiveness resulting from the internationalization process. Opening foreign markets enables a high potential for the company's expansion and growth and also provide feedback mechanisms for its technological capabilities. There is a trend that the Brazilian companies go to the global market with the purpose of seeking information to accomplish their technological innovation, and such kind of internationalization affects positively the companies' export performance (ARBIX et al., 2005).

\section{Internationalization strategy}

Internationalization of an organization can be understood as the result of strategic decisions, which move a company through different and successive stages in its internationalization process. According to the authors Douglas and Craig, each of these stages is followed by new and different challenges, and decision priorities will be encountered, and such priorities must be understood in the context of internationalization of each company under analysis. So, such stages may be understood in the context of different perspectives, resulting in a significant number of authors who have been busy in defining the internationalization process stages ( $\mathrm{OO}$ HANSON And Vahlne, 1977, Bilkey And Tesar, 1977, Cavusgil, 1980, Czinkota, 1982, And Reid, 198I).

In the theoretical field that addresses the companies' internationalization; different theories are usually grouped into two approaches, one of economic origin and the other of behavioral nature. Based on Cantwell (1991) and lettoGillies (1997), who gathered the main theories of international production and the description of theories relating to the economic approach, three theories are usually cited in the literature as the most influential: Theory of Market Power, Internalization Theory, and Eclectic Paradigm. The "behavioral" approaches gave origin to the so-called "stage models". Among them, the Uppsala model was the first, the most cited (LANGHOFF, 1997, Oviatt And Mcdougall, 1999) and most empirically tested (BELL, 1995, Petersen And Pedersen, 1997) in the literature. Two other important theoretical developments following the Uppsala Model are often

ISSN: 07 I8-2724. (http://www.jotmi.org)

Journal of Technology Management \& Innovation (c) Universidad Alberto Hurtado, Facultad de Economía y Negocios. 
cited in the literature (JOHANSON And Vahlne, 1990, 2003, Knight, 2000): international entrepreneurship and network prospects.

A literature review of several studies point to the fact that "economic" models describe and explain better the choice of entry modes and location of the production facilities by large companies based on developed countries and already operating in the most advanced stages of the internationalization process (MNCs, or multinational companies). They seek to explain how the market, the industry and the company's characteristics can be taken into account when deciding on the "best" way to expand globally. In contrast, the "behavioral" models would describe better how small companies or those with little international experience would be internationalized.

According to Fleury and Fleury (2007), the intrinsic decisions to the internationalization process are the choice of the country, control structures, products, transference of know-how, management models, etc., and the existing approaches propose three ways to focus on the internationalization process. The first sees the organization as a whole and elects the head office as the interlocution center; the second is concerned with focusing the subsidiary companies as the center of operations, with the idea that each one can "live by itself", with individual strategies and behaviors and operate independently from the head office; the third is basically concerned with the production system in the internationalization processes.

It can also be mentioned that the most representative theories, as cited above, can also be complementary in some aspects, although according to the authors they do not respond entirely to the issues relating to the management of internationalization or consolidation of international business studies. The inclusion of valid theories to new issues is of the early 1980s. The multidisciplinary is due to the educational background of the authors who were precursors in the field, mostly Anglo-Americans, which is the biggest problem of the area (DYMSZA, 1984). All theories have contributed in different ways for the understanding of the internationalization process. In Brazil, one of the difficulties of some of the approaches mentioned is that all models are based on other countries' processes and this hardly explains the country's reality (REZENDE, 20I0).

Even with such perspectid, which points at the difficulty of formulating adequate theories, and the late entry of companies from emerging countries such as Brazil in the international market, one can understand that the process exists and has been developed with incentives provided by the market itself (competitiveness), government's incentives, and business opportunities with gains outside the country. It is known that there is need for further learning and incorporation of the theories to the local reality, but the Brazilian organizations are seeking to reach global markets through increments, innovation and differentiation. According to Rocha, Silva and Carneiro (2007), one of the best-known hypotheses for such late internationalization and low investments is the big domestic market and the degree of reluctance toward international competition.

The internationalization process of a company and the relevant decision to invest in a foreign country are made upon very consistent considerations in terms of strategies, performance and economy, when compared with the decision of investing in the own country. These companies consider as the main motivation for investments the opening of new markets, new raw materials, production efficiency, knowledge, and political safety (MEINERZ, 1999 Apud Mota, 2007).

Under this perspective of choices and strategies, the organization understands that the operations internationalization process also requires it to be fully prepared to cope with potential barriers for its installation. It is necessary that the company that is willing to operate internationally understands that investments will be needed to overcome all obstacles that will arise in the export process, which result either from market characteristics, such as non-tariff barriers, institutional or cultural restraints, or regarding the exported product (IGLESIAS And Motta Veiga, 2002).

According to Adelino (1999), when companies have competitive edge resulting from its ability to innovate, they try to maximize the benefits of such competitiveness and tend to increase their market share. Internationalized operations are one of the most common mechanisms to move forward with the optimized capabilities provided by innovation and convert it into competitive advantage in increasingly competitive markets.

Operations internationalization has been seen as a strategy to ensure expansion or market gains for companies that seek new businesses and opportunities.

\section{Method}

This research is a descriptive and qualitative investigation using the case study method. According to Gil (1999), a descriptive research aims to detail the characteristics of a population and phenomenon and establish a relation between variables.Yin (200I) defines a case study as a research strategy intended to investigate a phenomenon in its context, obtain its characteristics and achieve the goal of the study. The selection of the company for data collection and analysis was intentional. Because the chosen company is renowned for its innovative activity and judicious development of prod- 
ucts with low environmental impact, the "gaúcha" company with activities in the chemical sector also presented a relevant international performance, as shown by the growth of exports in 2009.

Data were collected from the information available in the company's website, on sustainability reports divulged by the company and in the semi-structured interview with its technology manager. The area of technology is led by a professional with 20 years of experience and educational background in production engineering. The data analysis was done using the method of content analysis, which is defined by Bardin (1977, p. 46) as "handling messages to show the indicators that enable to infer about a reality that is not the message".

The research conceptual model was developed and adapted based on the variables of the Survey on Technological
Innovation (Pesquisa da Inovação Tecnológica- PINTEC) (IBGE, 2007), on the sustainable innovation framework developed by Hansen et al. (2009) and on the international performance concepts presented by Zou, Taylor and Osland (1998) and Shoham (1998).

Based on the described model, this study seeks to prove the following assumption:

The management of sustainability-oriented technology innovation is associated with the process of increased international competitiveness.

Among the variables considered in PINTEC of IBGE (2007) for evaluation of corporate innovation activities, we used those considered more appropriate for the purposes of this study, as described below:

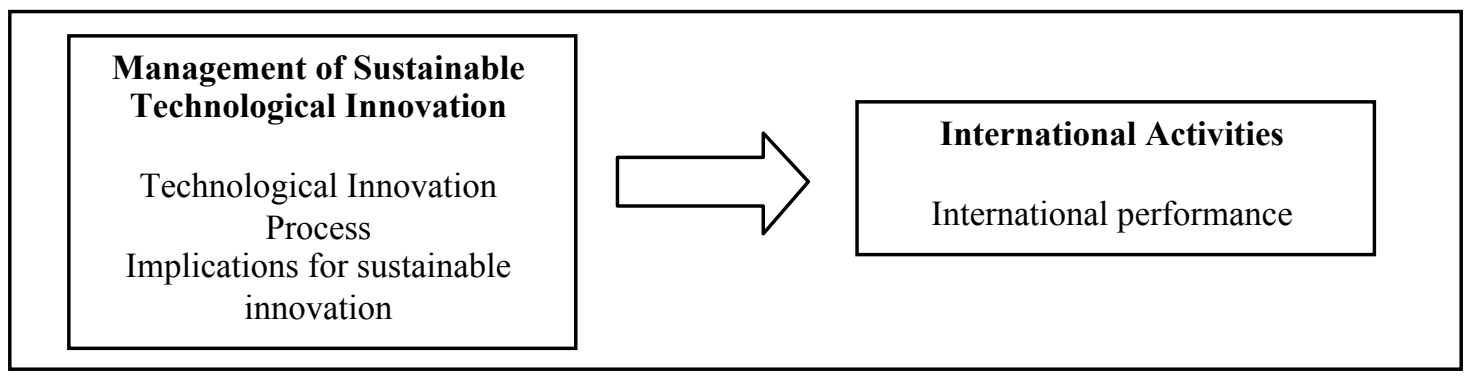

Figure I - Conceptual model of research

Source:Adapted from IBGE (2007), Hansen et al. (2009), Zou, Taylor and Osland (1998) and Shoham (1998).

\begin{tabular}{|l|}
\hline Innovative Activity \\
\hline Innovative activities; \\
In-house R\&D activities; \\
Innovation impacts; \\
Information sources; \\
Cooperation relations for innovation; \\
Government support; \\
Patents and other protection methods; \\
Problems and obstacles to innovation; \\
Other important organizational and strategic changes \\
\hline Sustainable innovation \\
\hline Integration of the sustainability criterion in the development of a new product or process; \\
Integration of stakeholders and users in the decision-making process of new products or processes development; \\
Sustainability-oriented marketing of sustainable innovation \\
Sensitization of decision-makers on sustainability concepts \\
\hline International performance \\
\hline Financial and strategic performance; \\
Satisfaction with the international operations; \\
Exports income, exports volume and market share \\
\hline
\end{tabular}

$$
\text { Chart I - Dimensions of analysis }
$$

ISSN: 07 I8-2724. (http://www.jotmi.org) 
For evaluation of the sustainable innovation we considered the model proposed by Hansen et al. (2009), for practical implications on the sustainable innovation management. The international performance is based on Zou, Taylor and Osland (1998), who described subjective indicators, and on Shoham (1998), who presents objective indicators.

\section{Data analysis}

The data analysis is structured into two sections: company's characterization and analysis of the model categories.

\section{Company's characterization}

For the purposes of this study, the focus company of this research will be called QUIMICAS. It was founded in 1948 and began its activities as a manufacturer of paints and glues. Currently, it is a group that controls many companies in Brazil (I 0 plants) and Latin America, producing adhesives, special veneers, engineering plastics and PPE (Personal Protection Equipment) for the most diverse markets. The adhesives are used in the industries of footwear, timber, furniture, paper and packaging, automotive, and construction. The veneers form components for shoes, counters, insoles and linings. The edge tapes made of PVC are used in the furniture industry in Brazil and Latin America. The thermo-moldable structural plates contain natural fibers in their composition, as is the case of the product consisting of ecological fiber that is used particularly by the automotive industry in the car structure and interior lining, and other industries.

The main characteristics that make up the profile of the company under analysis are presented in Chart 2.

QUIMICAS has remarkable social activity accomplished by the foundation participant in the Social Partnership Network, which has as members the government of the state of Rio Grande do Sul, private companies, and non-governmental organizations, and has the objective of undertaking social projects, according to the Solidarity Law. The foundation is registered in the Secretariat of Justice and Social
Development of Rio Grande do Sul, as is qualified as Civil Society Organization of Public Interest (OSCIP). The actions developed by the foundation are recognized and consist of numerous projects, also involving the local community. Quimicas sponsors several projects designed by the foundation, having benefited II entities and 520 persons in Rio Grande do Sul in 2009 through qualification programs to generate jobs and income also from craftworks; qualification for the development of management skills with focus on sustainability; environment-oriented qualification for jobs, and strengthening of ethic and moral principles.

\section{Management of sustainable technological innovation}

The results of the study are structured according to the categories, as follows: sustainability-oriented management and the relations between innovation management oriented to sustainable development and the global performance of the company.

\section{Sustainability-oriented process for innovation management}

The first ideas about sustainability were introduced to the company in the 1980s, when natural fibers became part of the composition of some products, such as sawdust wastes produced by the furniture industry, as a component of shoes structuring material. The search for new sources of raw materials to maximize energy and optimize time was becoming part of the company's goals. A partnership with an Italian plate manufacturer for the automotive industry prompted the production of plastic from sugarcane fiber. Such panels are used in car doors and opened new business opportunities for the company.

The concern with sustainable aspect is present in the search for cleaner production processes, from the product development to its final use by consumers. Wastes are treated as they are generated and not when discarded, and this reduces the production of wastes, which are also reused.

\begin{tabular}{|l|l|}
\hline Type of product & Industrial adhesives, special veneers, engineering plastics, special protective shoes \\
\hline Number of employees & Large-size company (IBGE) \\
\hline Gross operational income in 2009 & R\$ 261 million \\
\hline Capital & Privately-held company \\
\hline Origin of controlling capital & National \\
\hline$\%$ of exports in gross operational income & $25 \%$ \\
\hline Type of innovation & Product and process \\
\hline Location & Manufacturing facilities in Brazil and several countries in Latin America \\
\hline
\end{tabular}

Chart2 - Profile of QUIMICAS company. Source: Company's website and reports.

ISSN: 07 I8-2724. (http://www.jotmi.org)

Journal of Technology Management \& Innovation (c) Universidad Alberto Hurtado, Facultad de Economía y Negocios. 
The information sources for technology production are internal and external. Internally, the company encourages new ideas from collaborators, and externally by means of partnerships with high-tech, particularly from Europe, and currently with universities and research centers. The staff allocated to the R\&D sector is made up of professionals with high technical skills and academic training with a master's or doctoral degree.

Recently, QUIMICAS and the Studies and Projects Financing Agency (FINEP) have started a financing model for innovation. It consists of investment on innovation internationalization. In total, R\$ 16.33 million with public and private funds will be invested in the company units, either in Brazil and abroad, $49 \%$ of this amount being for investments in Argentina, Chile, Colombia, Mexico, and Peru. The other half will be used to qualify the innovation systems in the units of Rio Grande do Sul and São Paulo. The partnership with FINEP is not new: three projects were undertaken, resulting in the development of innovative products, such as the ecological fibers line (ANPEI, 20I0).

Product launches with sustainability appeal is treated with serious consideration because the company believes that the market is not so demanding with respect to the ecological and social characteristic of the products, but there exists a huge potential.The market has been asking for... but still is in its infancy (words of the interviewee). In partnership with FINEP, a polymer of renewable vegetable source, i.e., biodegradable, was developed and has been sold to a small shoe maker that exports its entire production to France. The interviewee explains that in foreign countries, particularly in Europe, there is much more demand for these products and considers as a barrier for the acceptance of products like that, with lower environmental impact, the large amount of plastic polymers from oil sources that is available in the marketplace. Clients and consumers do not yet feel the need of products from entirely renewable or biodegradable sources, and so it is an incipient process.

In this regard, the company's role is clearly stated in this context: But what is up to us? To be ready; not just have the technology available, but promote it, showing the pros and cons that final consumers and our clients will have with it (words of the interviewee). Right now, the partnership with universities and research centers is very important not only for products development, but also for publication of articles related to the cases of QUIMICAS' products and projects with the assistance of professors from the postgraduate program of a local university.

An example of this partnership is the study of Borchardt et al. (20I I), in which they analyzed the implementation of ecodesign and practices during the redesign of a product used to reinforce shoes. As a result, there was a cost reduction of about $10 \%$ and a decreased use of non-recyclable materials. Toxic materials were totally eliminated, and power consumption also decreased. This research also showed that improvements in products design might also contribute to less environmental impact and costs reduction, because several applications of solvents and adhesives that are aggressive and cause insalubrities problems were eliminated from the process. This case is an example of the importance given by the company to the disclosure of projects that they develop. But not always when there is a change in the product composition that the company decides to file a patent application, because the interviewee says that INPI (National Institute of Industrial Property) does not accept a new application only by substituting a natural fiber for another in the product composition. In this case, the company decides for industrial secrecy and for the retention of talented employees to reduce risks of spying and undue flow of information going out from the company.

In order that the technological innovations meet the criteria of sustainable development, the company invests on the training of decision-makers on sustainability. The company promotes a technology forum with all key people in the group, either in or out the country, and during three days they discuss issues such as product innovation, sustainability, qualification of people in compliance with ISO 9000 and 14000, among other subjects.

\section{Management of sustainable innovation and the company's international performance}

The integration of QUIMICAS into the foreign market took place via acquisitions and joint ventures. International partnerships began in the 1980s, but exports had already been part of its operations since 1963.

Firms with management and structure that are open to higher investments usually climb after the first exports to higher stages of involvement and commitment of resources such as subsidiaries, agents abroad, etc., which is ratified by the interviewee: In the international market, we operate both with exports and local production. Some products come out of Brazil to our units in Mexico, Colombia and Argentina. But they also go directly to clients [...] the company exports from here to the country and also exports from here to the unit abroad, it sells and produces locally too. These are the three mechanisms, the three forms of trade.

The evolution of international management involves developing strategic partnerships with foreign companies, aiming at acquiring know-how for the development of products and organizational growth:The Company is continuously developing new products. From the very beginning we considered 
partnerships with top companies, mainly in Europe. We had a 23-year partnership with a leading company in technology of this kind of shoe components. Over these 23 years, the technological growth was huge [...] such partnerships have a very clear objective, which is to make our businesses prosper and have a differential.

We can clearly see the fine line existing between internationalization strategies (either to integrate into, or remain in the market) and the innovation processes, once in many situations the theme is associated with the other. The need or intention can take a company into the international market, but its permanence or survival will depend on innovative processes and/or products perceived by the clients and the market, bringing positive results to the company: Today, Latin America represents $27 \%$ of the net revenues, so nearly $1 / 3$ comes from businesses abroad, says the interviewee. The international businesses have been seen as another market opportunity for the company and it will depend on it, on the possibility of taking risks and investing in research and development to ensure its survival and consolidate its market share.

In addition, there is the notion that each location can offer different advantages but also diverse obstacles, according to the investments, needs and local laws, so a management style that integrates processes, areas and objectives is important, as the interviewee explains: [...] that which is generated abroad [production wastes] I can't have it back, so I need to develop local productions to make it worth. Each country requires particular management, and each one has to deal with its own problems.

However, it is not possible to conclude that the sustainable technological innovation has influence on the company's international performance, but from such move towards to less aggressive products and processes to the environment emerges an opportunity for international businesses with more receptive countries such as those in Europe.

The interviewee emphasizes the need to create sustainable products with suitable costs, where equilibrium between production and selling price is possible. This can put a product that causes less damage to the environment into the market, and at the same time be competitive with similar existing products, bringing then the differential of preservation or product composition. Thus, the international management consolidates not only partnerships, but also the exchange of information, technology, and business opportunities that represents much of the company's revenues.

\section{Final considerations}

Based on the adapted variables of the model, this study aimed to identify how management of sustainable technology innovation takes place and determine whether the management of sustainable technology innovation is associated with the increased competitiveness of a firm in the international market.

The results of the analyses allow us to conclude that QUIMICAS fits the argument of Arbix et al. (2005) regarding internationalization to achieve technological capabilities, which leads to an increased potential of expansion and growth.

The integration of the concepts relating to sustainable development of products and processes is intensive and this results from the company's jointly efforts with research institutes and financing agencies (such as FINEP), employees, in addition to joint ventures, investments on personnel, and acquisition of companies.

QUIMICAS understands that its role is to play in the context of sustainable development when it uses and discloses some of new technologies, always securing its industrial property. However, although the company has been making efforts to adapt its productive process and strategic management to the sustainability-related paradigm, the local market is not as receptive to the products with sustainable appeal as the European market is. Thus, the company's international performance cannot be linked to the investments on sustainable innovations, once Europe is a more receptive market and demands more products with low environmental impact, but they are the sales to Latin America that account for most of the net income.As mentioned earlier in this article, the variables may be interconnected so that the technological innovation may be a motivator for seeking international partnerships, as innovations of the most diverse types, including sustainable innovations, may turn into business opportunities in the domestic and international market. 


\section{References}

ASSOCIAÇÃO Brasileira Da Indústria Química - Abiquim. (2010). Website. http://www.abiquim.org.br [Acessed december I5, 20I0].

ADELINO, J.N. (1999) O ponto de partida: a procura de valor e a inovação. Sociedade portuguesa. Website. http:// www.spi.pt/documents/books/inovint/idie/experimentar/ introdu ção/cap_actual.htm [Acessed november 10, 20 I0]

ASSOCIAÇÃO Nacional De Pesquisa E Desenvolvimento De Empresas Inovadoras - Anpei. (20I0). Website. http:// www.anpei.org .br/imprensa/noticias/finep-apoia-projetode-internacionalizacao/ [Acessed december 12, 2010].

ARBIX, G; Salerno, M.s.; De Negri, J.a. (2005). Internacionalização gera emprego e melhora a competitividade das firmas brasileiras. In: De Negri, J.a; Salerno, M.s. (Orgs). Inovações, padrões tecnológicos e desempenho das firmas industriais brasileiras. IPEA, Brasília.

BARAÑANO, A.M. (1998). A relação entre a inovação e a dimensão de empresas. Paper presented at $X X$ Simpósio de Gestão da Inovação Tecnológica, São Paulo, Brazil.

BARDIN, L. (I 977). Análise de conteúdo. Edições 70, Lisboa. BELL, J. (1995). The internationalization of small computer software firms: A further challenge to "stage" theories. European Journal of Marketing, p. 60-75.

BILKEY,W.; Tesar, G. (1977). The export behavior of smaller sizedWisconsin manufacturing firms. Journal of International Business Studies, 8(I), p. 93-98.

BORCHARDT, M.; Wendt, M.; Pereira, G.; Sellito, M. (20II). Redesign of a component based on ecodesign practices: environmental impact and cost reduction achievements. Journal of Cleanner Production, 19(I), p. 49-57.

CASSIMAN, B.; Veugelers, R. (2000). External technology sources: embodied or disembodied technology acquisition, University Pompeu Fabra, Economics and Business Working Paper No. 444. Available at SSRN: http://ssrn.com/abstract $=224582$ or http://dx.doi.org//0.2I39/ssrn.224582 [Acessed April 15, 20I0].

CARNEIRO, J.; Dib, L.a. (2007). Avaliação Comparativa Do Escopo Descritivo E Explanatório Dos Principais Modelos De Internacionalização De Empresas. Internext - Revista Eletrônica de Negócios Internacionais da ESPM, São Paulo, 2(I), p. I-25.
CAVUSGIL, S.T. (1980). On the Internationalization Process of Firms. European Research, 8(6), p. 273-28I.

CZINKOTA, M. (1982). Export Management. Praeger Publishers, New York.

DOUGLAS, S.P.; Craig, C.s. (1992). Advances in international marketing. International Journal of Research in Marketing, 9(4), p.29|-3I8.

GIL, A.C. (1999). Métodos e técnicas de pesquisa social. Atlas, São Paulo.

GUEDES, A.L. (2007). Negócios internacionais e gestão internacional: de onde viemos e para onde vamos? Paper presented at XXXI Encontro da Anpad, Rio De Janeiro, Brazil.

Damanpour, F. (I99|). Organizational innovation: a metaanalysis of effects of determinants and moderators.Academy of Management Journal, v. 34, n. 3, p. 555-590.

DAROIT, D.; Nascimento, L.f. (2000). A Busca Da Qualidade Ambiental Como Incentivo À Produção De Inovações. Paper Presented At Xxiv Encontro Da Anpad, Florianópolis, Brazil.

DE NEGRI, J.A.;Salerno, M.s.; Castro, A.b. (2005). Inovações, Padrões Tecnológicos E Desempenho Das Firmas Industriais Brasileiras. In: De Negri, J.a.; Salerno, M.s. (Orgs.). Inovações, Padrões Tecnológicos E Desempenho Das Firmas Industriais Brasileiras. Ipea, Brasília.

DYMSZA, W.A. (1984). Trends in multinational business and global environments: a perspective. Journal of International Business Studies, I5(3), p. 19-24.

FERRAZ, J.C.; Kupfer, D.; Haguenauer, L. (1995). Made In Brazil: Desafios Competitivos para a indústria. Campus, Rio de Janeiro.

FLEURY, A. e Fleury, M.t. (2007). Internacionalização das empresas brasileiras: em busca de uma abordagem teórica para os late movers. In: FLEURY, A; FLEURY, M.T. (orgs). Internacionalização e os países emergentes. Atlas, São Paulo.

GUEDES, A.L. (2007). Negócios internacionais e gestão internacional: de onde viemos e para onde vamos? Paper presented at XXXI Encontro da ANPAD, Rio de Janeiro.

GOMES, C.M. (2007). Gestão de fontes externas de informação tecnológica e desempenho inovador na empresa. Business Administration Doctoral Tese, Faculdade de Economia, Administração e Contabilidade da Universidade de São Paulo, São Paulo, Brazil. 
GENTZOGLANIS, A. (1997). Small and medium-sized firm's strategies and export performance: an empirical study. Ciencia Ergo Sum, 4(3), p. 255-264.

HANSEN, E; Grosse-Dunker, F; Reichwald, R. (2009). Sustainability Innovation Cube:A Framework To Evaluate Sustainability-Oriented Innovations. International Journal of Innovation Management, I3(4), p. 683-7|3.

IGLESIAS, R.M.; Motta Veiga, P. (2002). Promoção De Exportações Via Internacionalização Das Firmas De Capital Brasileiro. In: Pinheiro, A. C. Markwald, R.; Pereira, L.v. O desafio das exportações. BNDES, Rio de Janeiro, p. 369-446.

JOHANSON. J.; Vahlne, J. (1977). The internationalization process of the firm: a model of knowledge development and increasing market commitment. Journal of International Business Studies, 8, spring/summer.

(1990). The mechanisms of internationalization. International Marketing Review, 7(4), p. I I-24.

(2003). Business relationship learning and commitment in theinternationalization process. Journal of International Entrepreneurship, I, p.83-10I.

KNIGHT, G. A., (2000). Entrepreneurship and Marketing Strategy: The SME under Globalization, Journal of International Marketing, 8(2), p. I2-32.

LANGHOFF, T. (1997). The influence of cultural differences on internationalization processes of firms: an introduction to a semiotic and intercultural perspective. In: BJÖRKMAN, I.; FORSGREN, M. The Nature of the International Firm, Copenhagen Business School Press, Copenhagen.

LINDER, J.C.; Jarvenpaa, S.I.; Davenport, T.h. (2003). Toward An Innovation Sourcing Strategy. Mit Sloan Management Review. Cambridge, Ma,V. 44, n.4, p. 43.

MOTA, R.B. (2007). Decisões estratégicas no processo de internacionalização de empresas: "forma de entrada" e "seleção de mercado". Paper presented at III Encontro de Estudos em Estratégia da Anpad, São Paulo, Brazil.

INSTITUTO Brasileiro De Geografia E Estatística - Ibge. (2007). Pintec -Pesquisa de Inovação Tecnológica 2005. Rio de Janeiro, 2007. Website. http://www.pintec.ibge.gov.br/index.php?option $=$ com_content $\&$ view $=$ article $\& i d=45 \&$ Item id $=12$ [Acessed at December 20, 20I0]

OVIATT, B. M.; Mcdougall, P.p. (1999). A Framework For Understanding Accelerated International Entrepreneurship. In: Wright, R. Research in Global Strategic Management, JAI Press, Stamford, p. $23-40$.
PETERSEN, B.; Pedersen, T. 1997.Twenty Years After: Support And Critique Of The Uppsala Internationalization Model. In: Björkman, l.; Forsgren, M. The Nature of the International Firm, Copenhagen Business School Press, Copenhagen, p. II7- 34.

PORTER, M.; Van Der Linde, C. (1995). Toward A New Conception Of The Environment-Competitiveness Relationship. Journal Of Economics Perspectives, 9(4), P. 97-I I 8.

PORTO, G.S.; Prado, F.o.; Plonski, G.a. (2003). As Fontes De Tecnologia No Setor De Telecomunicações E Os Fatores Motivadores Para Cooperação. Espacios, 24(2). Website. Http://Www.revistaespacios.com/A03v24n02/032402 3I.Html [Acessed October 06, 2009].

QUADROS, R.; Furtado, A.; Bernardes, R.; Franco, E. (200I). Technological Innovation In Brazilian Industry: An Assessment Based On The São Paulo innovation survey. International Journal of Technological Forecasting and Social Change, 67(2).

REID, S. (1983). Firm internationalization: transaction costs \& strategic choice. International Marketing Review, p. 44-56.

REZENDE, S. F. (2010). Em direção a uma tipologia de processos de internacionalização. REA, São Paulo, 50(I), p.24-36.

ROCHA, A.; Silva, J. Da; Carneiro, J. (2007). Expansão Internacional Das Empresas Brasileiras: Expansão E Síntese. In: Fleury, A.; Fleury, M.t. (Org). Internacionalização e os Países Emergentes. Atlas, São Paulo.

SCHUMPETER, J.A. (1984). Capitalismo, socialismo e democracia. Zahar Editores S.A., Rio de Janeiro.

SHOHAM, A. Export Performance: a conceptualization and empirical assessment. (1998) Journal of International Marketing, 6(3), p.59-8I.

TIDD, J.; Bessant, J.; Pavitt, K. (1997). Managing innovation. Chichester, John Wiley\&Sons.

VIEIRA, V. M.; Ohayon, P. (2002). Novas Tendências Organizativas Das Atividades De P\&D: as redes de inovação tecnológica. Paper presented at XXVI Encontro da ANPAD, Salvador Brazil.

YIN, R.K. (200I). Estudo de caso: planejamento e métodos. Bookman, Porto Alegre.

ZOU, S.;Taylor, C.r.; Osland, G.e. (1998). The Experf Scale:A Cross-National Generalized Export Performance Measure. Journal Of International Marketing, 6(3), P. I0. 